\title{
Worldwide poisoning potential of Brugmansia and Datura
}

\author{
András Kerchner ${ }^{1} \cdot$ Ágnes Farkas ${ }^{2}$ (D) \\ Received: 20 June 2019 / Accepted: 23 August 2019 / Published online: 7 September 2019 \\ (c) The Author(s) 2019
}

\begin{abstract}
Purpose The toxicological significance of human exposures to angel's trumpet plants (Brugmansia and Datura species) in their native American and non-native regions (Asia, Africa, and Europe) was highlighted, and the poisoning potential of various plant parts was discussed.

Methods Nearly 2500 cases of human plant exposures, reported to the Hungarian Toxicological Information Service between 2005 and 2017, were analyzed and compared to data of other toxicology centers in America, Asia and Europe, focusing on exposures to tropane alkaloid-containing plants.

Results In America, Brugmansia and Datura were not among the 15 most common plant ingestions, but were responsible for $20 \%$ of the fatal outcomes in a 26-year period. In Asia, the anticholinergic toxidrome, related to Brugmansia and Datura, was among the most frequent plant-related intoxications, which included accidental ingestion, improper use of herbal medicines and plant abuse. In Europe, Brugmansia and Datura were among the top four plant taxa causing intoxications with major outcomes, being the leading plants ingested for their hallucinogenic properties, and accounted for $60 \%$ of abuse cases in Hungary in a 13-year period. Use of Brugmansia and Datura for criminal purposes has been reported from America, Asia and Europe. The concentrations of tropane alkaloids vary with the species, seasons and plant parts. Ingestion of the seeds and flowers has the highest toxicological significance, but exposure to the leaves and floral nectar can also cause intoxication. Conclusions Angel's trumpets have high toxicological significance both in their native and non-native regions, mainly due to their hallucinogenic property and accidental ingestion.
\end{abstract}

Keywords Abuse and accidental ingestion · Angel's trumpet · Atropine and scopolamine · Drug-facilitated robbery Suicide $\cdot$ Tropane alkaloids

\section{Introduction}

Data of poison control centers from several countries reveal that a significant proportion of all poisonings is related to plant exposures [1-4]. The most common causes of plantrelated toxicity are accidental ingestion of poisonous plant materials, misuse of herbal products, suicide attempts and abuse of hallucinogenic plants. The most frequently abused psychoactive plants include representatives of the Solanaceae family, such as Brugmansia and Datura species.

Ágnes Farkas

agnes.farkas@aok.pte.hu

1 Institute of Biology, Faculty of Natural Sciences, University of Pécs, Ifjúság u. 6, Pécs 7624, Hungary

2 Department of Pharmacognosy, Faculty of Pharmacy, University of Pécs, Rókus u. 2, Pécs 7624, Hungary
Datura species, also called thornapple, devil's apple, angel's trumpet (in a broad sense) or devil's trumpet, have their main center of origin in Mexico and the south-west United States (US) [5, 6]. Today, representatives of the genus Datura are considered as cosmopolitan and naturalized in many regions with tropical and temperate climate conditions [7], being widespread also in Africa, Asia and Europe, comprising noxious weeds or ornamentals. The genus includes annual herbs and perennial shrubs with erect and branched stems, alternate simple basal leaves and opposite leaves on terminal branches. The actinomorphic flowers are bisexual and pentamerous, with tubular corolla. The fruit is a spiny capsule with reniform seeds [8].

The genus Brugmansia was treated earlier as a subgenus or section of Datura. Today, arborescent species with pendulous flowers, native to South America are separated at the genus level, comprising B. arborea, B. aurea, B. candida, $B$. dolichocarpa, B. insignis, B. sanguinea, B. versicolor, and 
B. vulcanicola [9]. Most Brugmansia species had social and religious importance in ancient Andean cultures [10].

Both Brugmansia and Datura species are considered toxic, due to the presence of the tropane alkaloids atropine and scopolamine in each plant organ [11-19]. Atropine is known for its anticholinergic activity, causing mydriasis, blurred vision, suppressed salivation, vasodilation, tachycardia and delirium [20]. Scopolamine, also called hyoscine, is an antimuscarinic agent and a smooth muscle relaxant. Anticholinergic agents can be used in various fields of medicine, such as ophthalmology diagnostics, as antispasmodics, pre- and postoperative medications, analgesics, narcotics, sedatives, and also in treatments of asthma, Parkinson's disease and motion sickness [21-24].

Several cases of intoxication by ingestion of various parts of Brugmansia and Datura species have been reported [25-41]. Symptoms of intoxication include dilated pupils, confusion, hallucinations, dryness of skin and mucous membranes, increased blood pressure and heart rate, and increased body temperature [11, 36, 42-44]. Administration of physostigmine is the preferred treatment for severe cases of Datura poisoning, but due to controversies regarding potential adverse effects of physostigmine, it is not routinely applied in less severe cases, when supportive care and observation is satisfactory $[45,46]$.

Due to the fact that both Brugmansia and Datura taxa are becoming widespread worldwide-partly as a result of their successful reproductive strategies, and partly because being cultivated for ornamental purposes, their toxicological significance is increasing not only in tropical, but also in temperate regions of the world.

The objective of this article was to characterize human plant exposures that involve Brugmansia and Datura taxa in their native (America) and non-native regions (Asia, Africa, and Europe), and discuss the poisoning potential of various plant parts. To assess the worldwide toxicological significance of these tropane alkaloid-containing plants, a large number of cases were reviewed, based on toxicological center reports and case studies from several countries. To demonstrate the importance of plant-related anticholinergic intoxications in a European country, where Brugmansia and Datura are not native, data provided by the Hungarian Toxicological Information Service (HTIS) were analyzed in detail. In addition, we wanted to highlight differences in the poisoning potential of various plant parts, by analyzing data related to alkaloid concentrations in various plant parts and secretions, focusing on plant organs that have received less attention so far, such as the flowers and their secretory products.

\section{Analysis of toxicology center reports}

The 2005-2017 annual reports of the HTIS were reviewed to identify plant-related poisoning cases. Data were provided in a Microsoft Excel database by the HTIS. We analyzed a total of 2464 cases of human plant exposures and selected cases where the plant genera Brugmansia and Datura were involved. The data were analyzed to determine the frequency of poisonings, to identify the age and gender of those who were exposed, the reason for the exposure, and patient outcome. Descriptive statistics were used throughout the manuscript to characterize the data.

In addition, data of the HTIS were compared to similar data of other toxicology centers in the US [4], India [26], Taiwan [2], Switzerland [1] and Italy [3].

\section{Brugmansia and Datura poisonings in America}

From the native American region of Brugmansia and Datura species, we have toxicology reports from Canada, the US and Mexico.

Based on the annual reports of the American Association of Poison Control Centers (AAPCC) published for the years 1983-2009, the number of plant exposures reflected as a percentage of all exposures reported to US poison centers decreased from $8.9 \%$ in 1983 to $2.4 \%$ in 2009 [4]. Although Datura species were not among the 15 most common plant ingestions, hundreds of Datura intoxications occurred each year in the US. For example, in 1993, 318 Datura exposures were reported to the AAPCC; however, we can suspect that the true number of cases was even higher [47]. From the 45 fatalities recorded for a 26-year time period 1983-2009, Datura species were responsible for $20 \%$ of the fatal outcomes, being the leading cause of death attributed to plant exposures [4]. For the time period 1997-2001, an average of 1044 cases of anticholinergic plant exposures, including $D$. stramonium (jimson weed), was reported yearly in the US. Almost half (46\%) of the cases were due to abuse ingestion; $53 \%$ of patients had to be treated in health care facilities, and six deaths were reported. The majority (77\%) of cases occurred in individuals below 19 years of age [48]. According to the annual reports of the AAPCC, in the period of 2012-2017, neither Brugmansia nor Datura species were among the top 25 plant species involved in plant intoxications in the US [49-54].

In the US and Canada, Datura poisoning has been reported primarily among adolescents who abuse the plant for its hallucinogenic effects (Table 1) [29, 32, 45, 48]. The most frequently reported Datura species is D. stramonium, which grows wildly throughout the US and the southern 


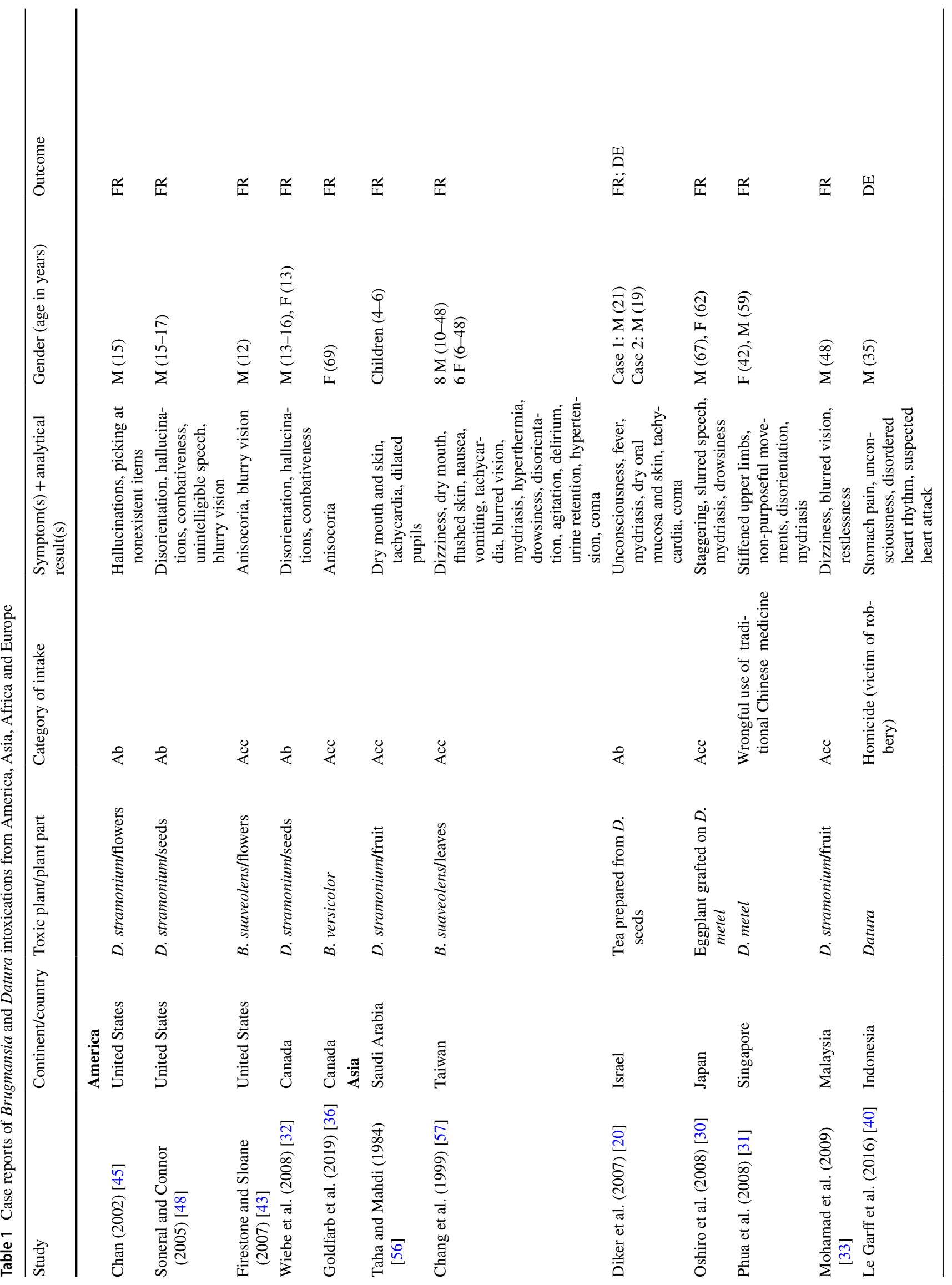




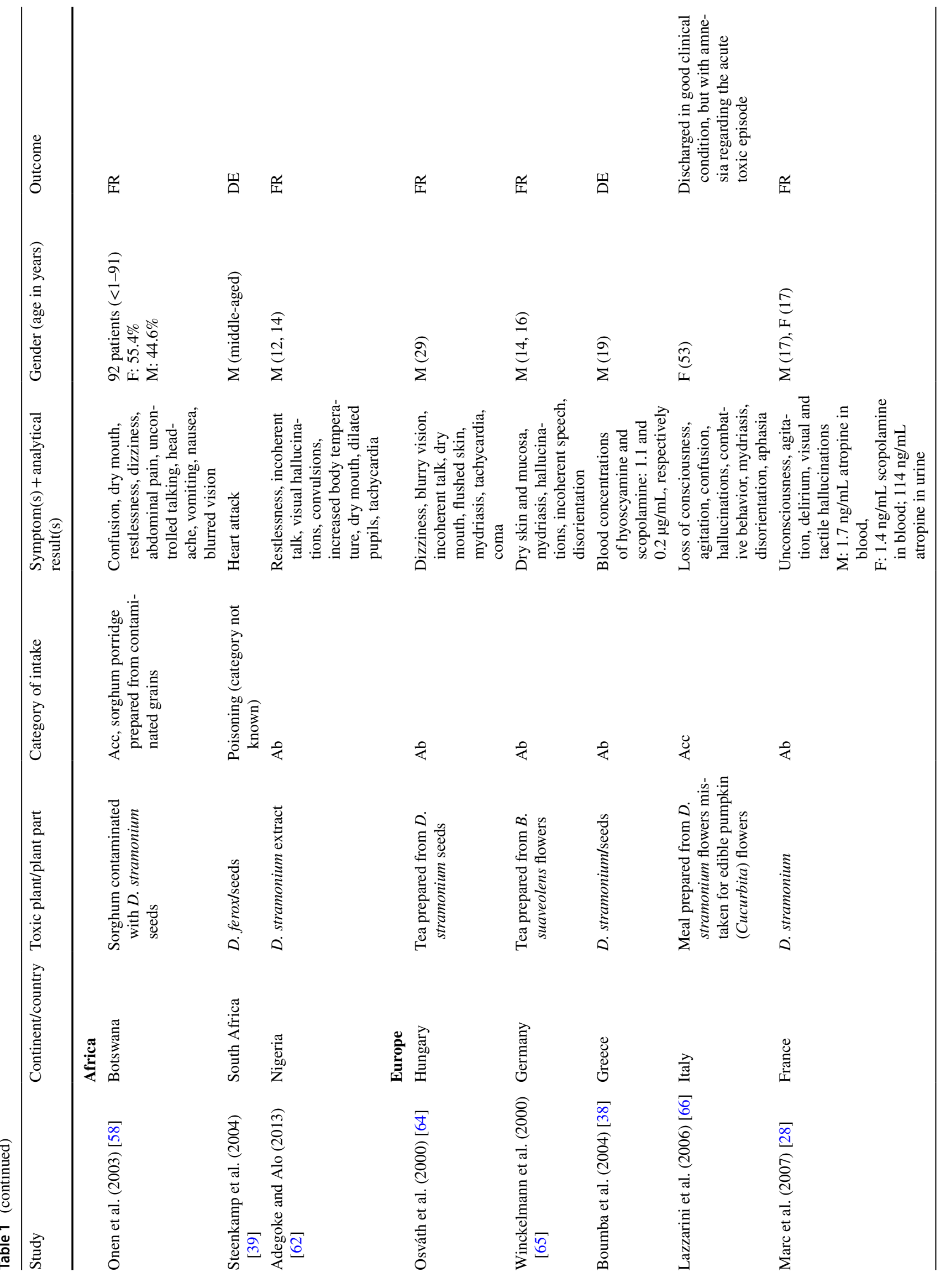




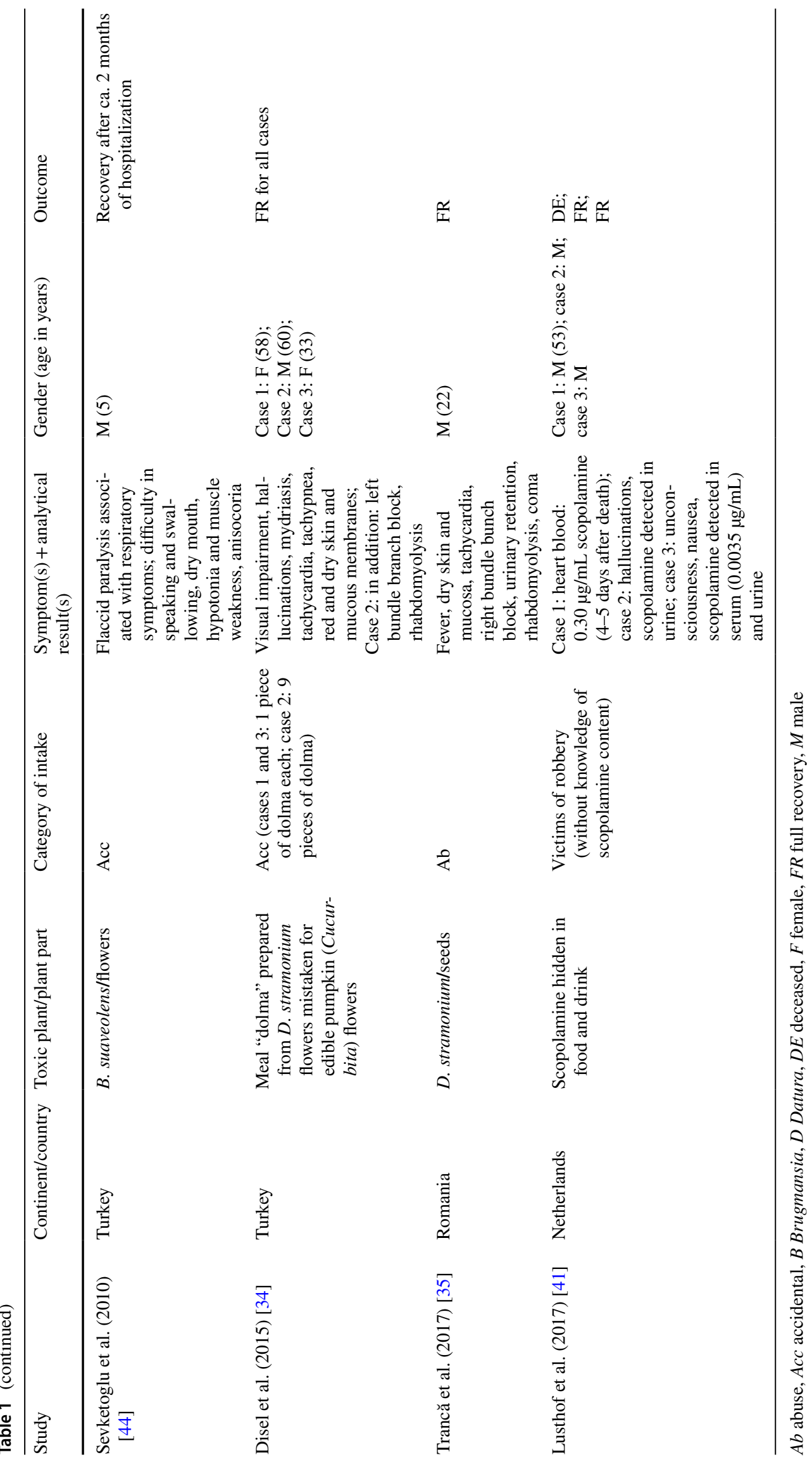


parts of Canada. Another common cause of intoxication can be gardening activity related to various Brugmansia taxa (angel's trumpets in a narrow sense), which are frequently grown as ornamentals [36]. In case of children, playing around Brugmansia plants and getting in contact with certain plant parts, e.g., the flowers, can also lead to symptoms of intoxication (Table 1) [43].

In Mexico, the most widely distributed Datura species are $D$. discolor and $D$. stramonium. Here, the most frequent causes of intoxication include the use of Datura in traditional shamanic medicine, accidental ingestion by children, and abuse in adolescents and adults [7].

\section{Brugmansia and Datura poisonings in Asia and Africa}

Poisoning cases with Datura have been frequently reported from Asia and Africa. In India, the total number of intoxication cases registered in a 3-year period (1999-2002) was 2720 , out of which $1.5 \%$ was due to plant exposures. Children under the age of 18 years were involved in 15 cases related to toxic plants, out of which 10 cases $(66 \%)$ were attributed to intoxication with various Datura species [26, 27]. Although the number of registered cases of plant intoxications seems to be very low for the country and population of this size-most probably due to underreporting - , the high ratio of Datura poisonings indicates by all means the significant poisoning potential of this plant genus in India. Accidental poisoning may occur when Datura seeds, resembling capsicum seeds, are mistakenly ingested. Consumption of wasp honey contaminated with Datura may also lead to poisoning [55]. Cases of accidental D. stramonium ingestion have been reported also from Saudi Arabia [56]. In Taiwan, 1414 plant-related poisoning cases were recorded in a 20-year period (1987-2006). Regarding the 389 cases of single-plant exposures, the most frequent type of intoxication, the anticholinergic toxidrome, was related to Brugmansia or Datura species. In adults, B. suaveolens (19\%) and D. metel (16\%) were the top two commonly ingested poisonous plants $[2,57]$. Datura species may even cause intoxication when an otherwise edible plant is grafted on them, as in a case reported from Japan [30]. Mass poisoning was reported from Botswana, after consuming sorghum flour contaminated with Datura seeds [58] (Table 1).

In Ayurvedic medicine, in India, D. stramonium has been used to treat various health problems, such as inflammations, ulcers, wounds, rheumatism, gout, fever, asthma and bronchitis, and as a painkiller in headache or toothache. The external use, e.g., in the form of paste or solution to relieve local pain, may not have a deleterious effect; however, internal use may lead to severe anticholinergic symptoms [59]. In addition, some Chinese herbal medicines (CHM) contain anticholinergic agents. For example, "yangjinghua", the dried flower of $D$. metel, has been used for treatment of bronchial asthma, bronchitis, pains and flu symptoms [31, 60]. In Malaysia, "kecubung" (Datura) is eaten as a traditional medicine to treat allergic rhinitis. In Africa, D. stramonium and $D$. ferox are frequently used in traditional medicine, mainly to relieve asthma and to reduce pain [61]. Inaccurate doses, improper use of traditional herbal medicines or contamination of $\mathrm{CHM}$ with atropine-like substances may lead to severe or even fatal anticholinergic toxidrome [33, 60] (Table 1).

Besides accidental ingestion and wrongful use of traditional herbal medicines, intoxication with Datura extracts occurred most frequently when they were abused for hallucinogenic effects [20,62], or due to crime-related poisoning $[39,40]$ (Table 1).

\section{Brugmansia and Datura poisonings in Europe}

From the Datura genus, three species, D. ferox, D. innoxia and $D$. stramonium are widely distributed and naturalized in several European countries [63]. From Europe, we had access to data of national poison control centers in three countries, Hungary, Italy and Switzerland.

In Hungary, 2464 cases of contact with or ingestion of toxic plant material were registered in the period 2005-2017. During this interval, there has been an increasing tendency in the number of plant exposures (Fig. 1), in contrast to the decreasing tendency observed in the US [4]. Unlike in the US, but similarly to India and Taiwan, Brugmansia and Datura were among the species involved in the largest number of plant-related poisonings in Hungary. The top four plant taxa that regularly caused intoxications in Hungary were Brugmansia and Datura species, Convallaria majalis and Taxus baccata, accounting for 1-7\%, 1-16\%, 6-20\%, and $8-19 \%$ of all plant-related intoxications, respectively, in the period 2005-2017 (Fig. 2). As shown in Table 2, the number of Brugmansia and Datura poisoning cases in Hungary was fluctuating from year to year, with no clear-cut tendency for the proportion of anticholinergic exposures. However, in the last five years of the study, the number of such poisoning cases was on the decrease. This could be due to several reasons: (1) Hungarian people became better informed regarding the risks of ingesting Brugmansia or Datura plant parts or extracts, and thus avoided exposure to these plants; (2) adolescents and young adults started to use other natural or synthetic drugs for their hallucinogenic properties; (3) not all cases were reported to the toxicological center, probably due to milder symptoms of intoxication, when the affected individuals did not seek medical attention. In contrast to the US, where Datura intoxications were 


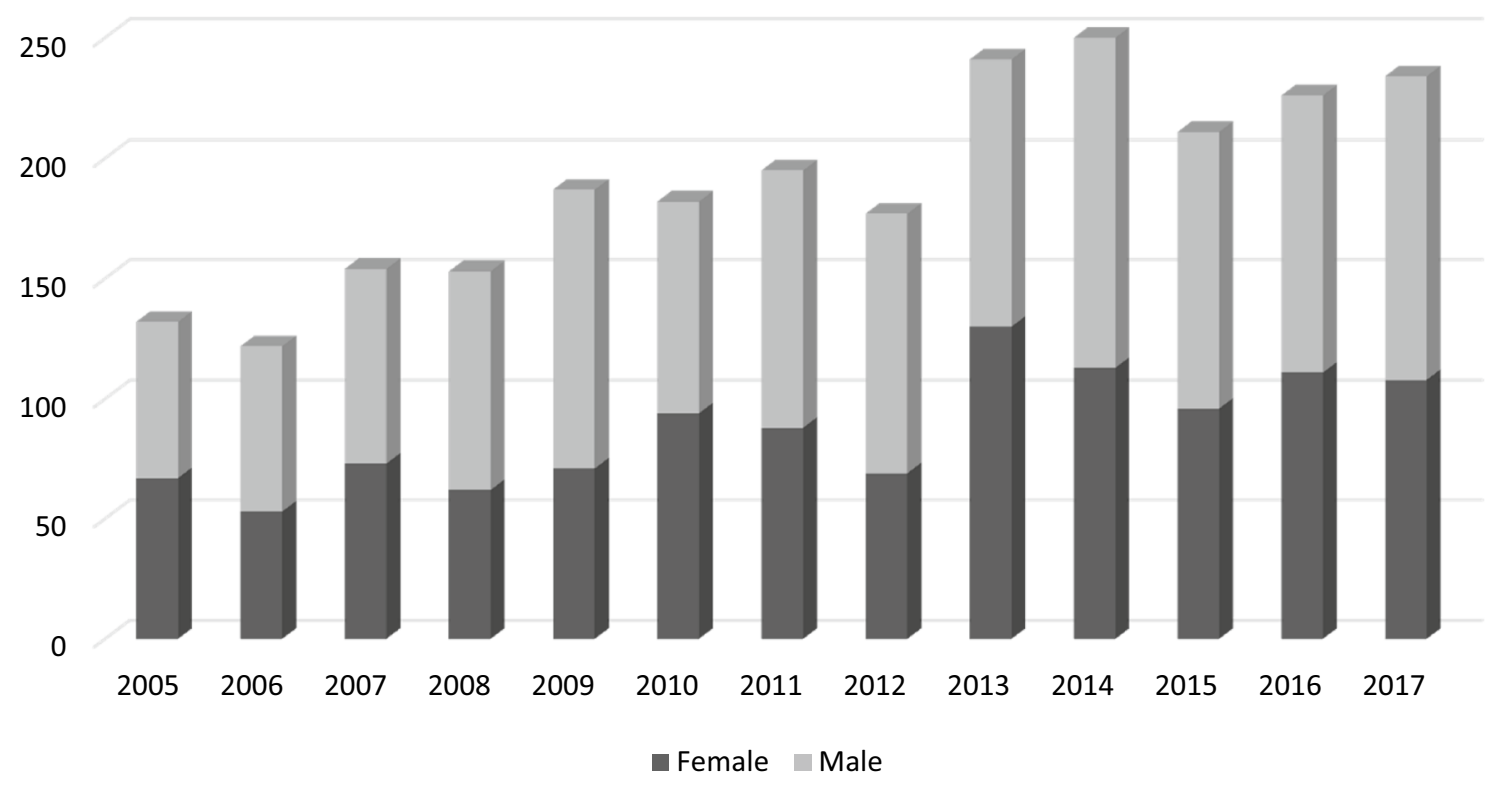

Fig. 1 Total annual numbers of all types of toxic herbal exposures in Hungary 2005-2017

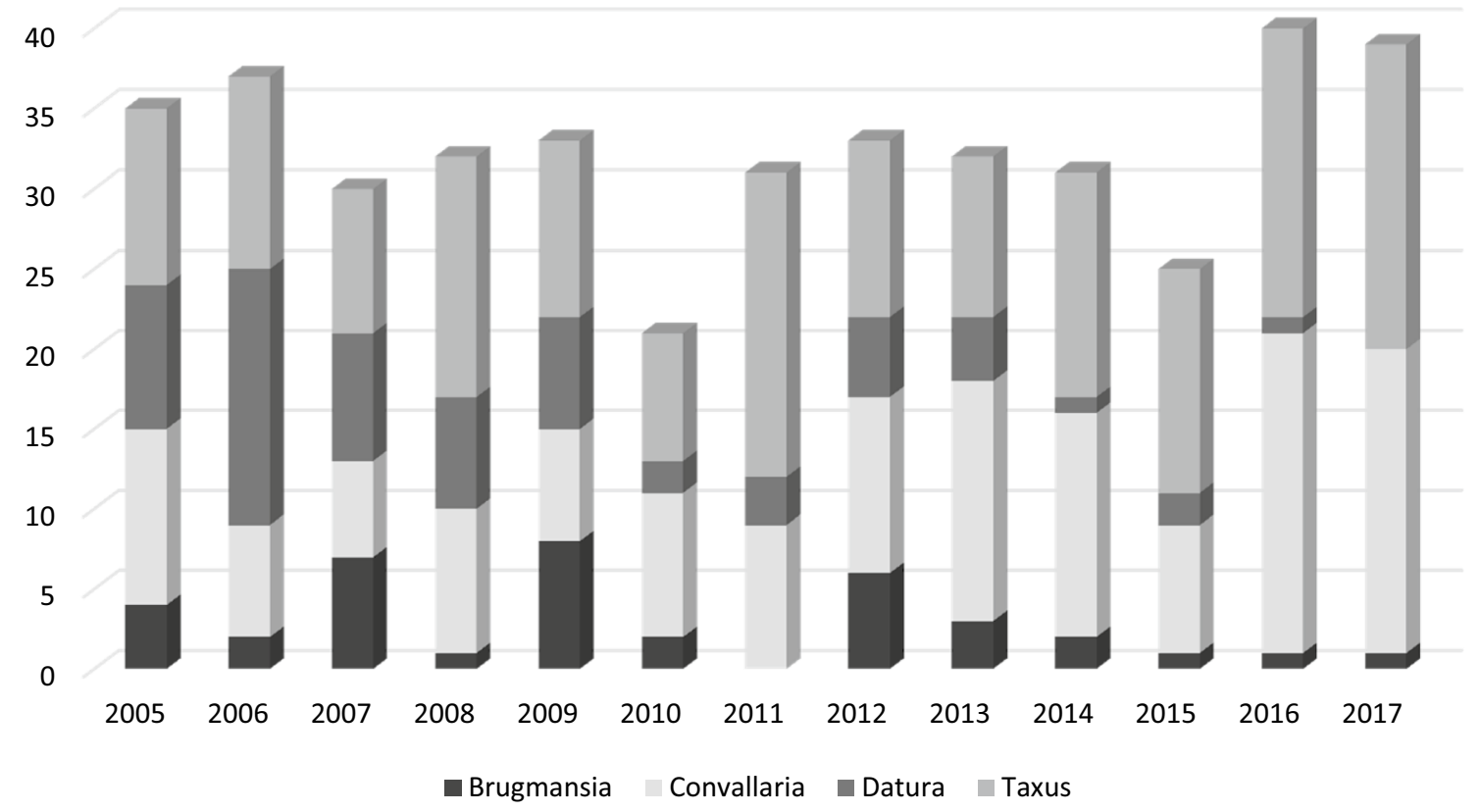

Fig. 2 Ratios (\%) of intoxications caused by the top four poisonous plants in Hungary 2005-2017

responsible for one-fifth of plant-related fatalities, in Hungary there were no fatal intoxications related to Brugmansia or Datura for a 13-year time period, even though $12 \%$ of major outcomes were related to these species.

Between 2005 and 2017 in Hungary, Brugmansia and Datura taxa were responsible for $60 \%$ of all plant abuse cases, being the leading plants ingested for their hallucinogenic properties [64] (Tables 1, 2), while they accounted for a much lower proportion (18\%) of suicide attempts. Considering all Brugmansia and Datura poisonings (167 cases), the percentage of abuse cases (60\%) was double of accidental ingestions (30\%), and only $10 \%$ was due to suicide attempts (Table 2). Intoxication with Brugmansia and Datura occurred mainly in the months August-October, which suggests that in most cases the fruits, and particularly the seeds are ingested. At this time of the year in temperate 
Table 2 Summary of Brugmansia and Datura poisonings that took place in Hungary in 2005-2017, reported to HTIS

\begin{tabular}{|c|c|c|c|c|c|c|c|}
\hline \multirow[t]{2}{*}{ Year of study } & \multicolumn{2}{|c|}{ Number of cases/plant part } & \multirow{2}{*}{ Co-ingestion } & \multirow{2}{*}{ Category of intake } & \multirow{2}{*}{ Age group } & \multirow[t]{2}{*}{ Gender } & \multirow[t]{2}{*}{ Outcome } \\
\hline & Brugmansia & Datura & & & & & \\
\hline 2005 & 5/flowers & $12 /$ seeds & $\begin{array}{l}\text { (1) } D+\text { alc; }(2) \\
B+\text { alc; }(3) \\
B+\text { benzodiaz- } \\
\text { epines }\end{array}$ & 6 Acc; 9 Ab; 2 Sui & 11 Ado; 6 Adu & $2 \mathrm{~F} ; 15 \mathrm{M}$ & $13 \mathrm{FR} ; 4 \mathrm{H}$ \\
\hline 2006 & 2/flowers & 19 & $\begin{array}{l}\text { (1) D. stramo- } \\
\text { nium + alc + white } \\
\text { powder + benzodi- } \\
\text { azepines }\end{array}$ & $\begin{array}{l}3 \text { Acc; } 17 \mathrm{Ab} ; 1 \\
\quad \text { Sui }\end{array}$ & $\begin{array}{l}2 \mathrm{Ch} \\
16 \mathrm{Ado} \\
3 \mathrm{Adu}\end{array}$ & $4 \mathrm{~F} ; 17 \mathrm{M}$ & $20 \mathrm{FR} ; 1 \mathrm{H}$ \\
\hline 2007 & 11/flowers & 14/fruit, seeds & $\begin{array}{l}\text { (1) } D+\text { alc; }(2) \\
D+\text { benzodiaz- } \\
\text { epines }\end{array}$ & $\begin{array}{l}4 \text { Acc; } 19 \text { Ab; } 2 \\
\text { Sui }\end{array}$ & $\begin{array}{l}3 \mathrm{Ch} ; 18 \text { Ado; } \\
4 \mathrm{Adu}\end{array}$ & $10 \mathrm{~F} ; 15 \mathrm{M}$ & $25 \mathrm{FR}$ \\
\hline 2008 & 2 & $10 /$ seeds & $\begin{array}{l}\text { (1) } D+\text { alc; }(2) \\
B+\text { benzodiaz- } \\
\text { epines }\end{array}$ & $5 \mathrm{Acc} ; 5 \mathrm{Ab} ; 2$ Sui & $\begin{array}{l}3 \text { Ch; } 6 \text { Ado; } \\
3 \text { Adu }\end{array}$ & $1 \mathrm{~F} ; 11 \mathrm{M}$ & $10 \mathrm{FR} ; 2 \mathrm{H}$ \\
\hline 2009 & 14 & $13 /$ seeds & $\begin{array}{l}\text { (1) D. stramo- } \\
\text { nium }+ \text { alc }\end{array}$ & $\begin{array}{l}8 \text { Acc; } 18 \mathrm{Ab} ; 1 \\
\quad \text { Sui }\end{array}$ & $\begin{array}{l}5 \text { Ch; } 14 \text { Ado; } 8 \\
\text { Adu }\end{array}$ & $6 \mathrm{~F} ; 21 \mathrm{M}$ & $22 \mathrm{FR} ; 5 \mathrm{H}$ \\
\hline 2010 & 3 & 3 & - & $2 \mathrm{Acc} ; 3 \mathrm{Ab} ; 1$ Sui & $\begin{array}{l}2 \mathrm{Ch} ; 2 \text { Ado; } 2 \\
\text { Adu }\end{array}$ & $1 \mathrm{~F} ; 5 \mathrm{M}$ & $5 \mathrm{FR} ; 1 \mathrm{H}$ \\
\hline 2011 & 0 & 5/seeds & - & $5 \mathrm{Ab}$ & 3 Ado; 2 Adu & $2 \mathrm{~F} ; 3 \mathrm{M}$ & $4 \mathrm{FR} ; 1 \mathrm{H}$ \\
\hline 2012 & $\begin{array}{l}\text { 11/sap, stem, } \\
\text { flower }\end{array}$ & 8 & - & $\begin{array}{l}4 \text { Acc; } 11 \mathrm{Ab} ; 4 \\
\text { Sui }\end{array}$ & $\begin{array}{l}2 \mathrm{Ch} ; 5 \text { Ado; } \\
12 \mathrm{Adu}\end{array}$ & $3 \mathrm{~F} ; 16 \mathrm{M}$ & $17 \mathrm{FR} ; 2 \mathrm{H}$ \\
\hline 2013 & 6/flower, sap & 9/seeds & (1) $B+$ zopiclone & $\begin{array}{l}4 \text { Acc; } 10 \mathrm{Ab} ; 1 \\
\text { Sui }\end{array}$ & $\begin{array}{l}3 \mathrm{Ch} ; 4 \text { Ado; } 8 \\
\text { Adu }\end{array}$ & $5 \mathrm{~F} ; 10 \mathrm{M}$ & $13 \mathrm{FR} ; 2 \mathrm{H}$ \\
\hline 2014 & 4 & 3 & - & $5 \mathrm{Acc} ; 2 \mathrm{Ab}$ & $\begin{array}{l}2 \mathrm{Ch} ; 1 \text { Ado; } 4 \\
\text { Adu }\end{array}$ & $3 \mathrm{~F} ; 4 \mathrm{M}$ & $7 \mathrm{FR}$ \\
\hline 2015 & 2 & 4 & - & $4 \mathrm{Acc} ; 1 \mathrm{Ab} ; 1$ Sui & $3 \mathrm{Ch} ; 3$ Adu & $2 \mathrm{~F} ; 4 \mathrm{M}$ & $4 \mathrm{FR}, 2 \mathrm{H}$ \\
\hline 2016 & 3 & 2 & $\begin{array}{l}\text { (1) D. stramo- } \\
\text { nium + cannabis }\end{array}$ & $3 \mathrm{Acc} ; 1 \mathrm{Ab} ; 1 \mathrm{Sui}$ & $\begin{array}{l}3 \mathrm{Ch} \\
2 \mathrm{Adu}\end{array}$ & $2 \mathrm{~F} ; 3 \mathrm{M}$ & $3 \mathrm{FR} ; 2 \mathrm{H}$ \\
\hline 2017 & 2 & 0 & - & $2 \mathrm{Acc}$ & $2 \mathrm{Ch}$ & $2 \mathrm{M}$ & $2 \mathrm{FR}$ \\
\hline Total & 65 & 102 & & $\begin{array}{l}50 \mathrm{Acc} ; 101 \mathrm{Ab} ; \\
16 \mathrm{Sui}\end{array}$ & $\begin{array}{l}30 \mathrm{Ch} ; \\
80 \mathrm{Ado} \\
57 \mathrm{Adu}\end{array}$ & $41 \mathrm{~F} ; 126 \mathrm{M}$ & 145 FR; $22 \mathrm{H}$ \\
\hline
\end{tabular}

(1) Case 1, (2) case 2, (3) case 3

$A b$ abuse, Acc accidental, Ado adolescent (13-18 years of age), Adu adult (older than 18 years), Alc alcohol, B Brugmansia, Ch children (younger than 13 years), $D$ Datura, $F$ female, $F R$ full recovery, $H$ further treated in hospital, HTIS Hungarian Toxicological Information Service, $M$ male, Sui suicide

climate, the plants are still in bloom, but at the same time several fruits have already developed on these plants. In most cases, Brugmansia and Datura were taken without any co-ingestants, but in a number of cases, they were ingested together with alcohol and/or psychoactive drugs, such as benzodiazepines (Table 2).

With regard to gender, $75 \%$ of all Brugmansia and Datura ingestions in Hungary occurred in males and only $25 \%$ in females in the period of 2005-2017 (Table 2). This indicates that males are three times more likely to suffer anticholinergic intoxication by plant origin than females, in most cases by taking the risk of ingesting various plant parts or extracts of Brugmansia or Datura for their hallucinogenic properties.

Data on the types, frequency and severity of plant poisonings are available from Switzerland for a 29 -year period
(1966-1994). From a total of 24,950 registered cases of intoxication with plant material, severe plant poisonings were reported in 152 cases. Out of these, 17 cases (11\%) were related to the ingestion of $D$. stramonium [1]. The Poison Control Center of Milan, the leading toxicological center in Italy, registered 4432 plant exposures for the time period 2001-2005. In the age group of 15-90 years, the second most frequent cause of plant-related intoxications was the recreational use of hallucinogenic species (41 cases, 7\%), including D. stramonium (26 cases, 63\%) [3].

In addition, we have several reports from other European countries about consuming Brugmansia or Datura for their hallucinogenic effect [28, 35, 38, 65]. Similarly, in Spain, Datura species are mainly used as recreational drugs, but recently the use for criminal purposes is increasing [7]. From 
the Netherlands, a series of scopolamine-facilitated robberies were reported, including some fatal cases [41] (Table 1).

Cases of accidental intoxication were reported from Italy and Turkey, when D. stramonium flowers were mistaken for the similarly trumpet-shaped pumpkin (Cucurbita sp.) flowers $[34,66]$, or B. suaveolens flowers were unintentionally ingested [44] (Table 1).

\section{Poisoning potential of various plant parts of Brugmansia and Datura species}

The concentrations of tropane alkaloids vary depending on the Brugmansia or Datura species, seasons of the year and the plant parts involved in the exposure $[16,17,19,46]$. The ratio of scopolamine and atropine in various plant organs was found to be species dependent, e.g., in D. innoxia, scopolamine was found to be predominant in all plant organs, while atropine levels were found to be higher as compared to scopolamine in leaf samples of D. metel [17]. Alkaloid levels may even differ in two varieties of the same species, the purple-flowered variety of D. stramonium (var. tatula) contained significantly higher alkaloid concentrations in all plant parts, except the stem, as compared to the whiteflowered variety (var. stramonium) [17].

The alkaloid content is influenced also by whether the plant is in the juvenile or the reproductive stage, being the highest when the plant is flowering [46]. A study on four Datura taxa revealed that the alkaloid content of the stem and the leaf significantly decreased with plant aging, i.e., during transition from summer to autumn [17].

The alkaloid content is generally the greatest in the flowers and the seeds of various Datura species (e.g., up to 0.61 and $0.66 \%$ in D. stramonium [67]; $0.1-0.8$ and $0.2-0.5 \%$ in the flowers and seeds of D. metel, respectively) [68], but in the case of $D$. metel similarly high alkaloid concentrations were reported for the leaves, as well $(0.5 \%)[67,68]$.

The atropine and scopolamine concentration of $D$. stramonium seeds was determined as 1283 and $678 \mu \mathrm{g} / \mathrm{g}$, respectively [69]. The seeds of D. metel were reported to contain 2788 and $2020 \mu \mathrm{g} / \mathrm{g} ;$ D. metel leaves 69.87 and $840.4 \mu \mathrm{g} / \mathrm{g}$; while $B$. pittieri leaves contained 64.67 and $448.2 \mu \mathrm{g} / \mathrm{g}$ of atropine and scopolamine, respectively [70]. Calculating with average alkaloid content data, $1 \mathrm{~g}$ Datura seed would contain $2.9 \mathrm{mg}$ atropine and $0.5 \mathrm{mg}$ scopolamine, which is already in the toxic range. Bioavailability depends on whether the seeds were chewed, ground or swallowed as a whole, and also whether some kind of extract was prepared from various plant parts or dried plant parts were smoked [46].

Scopolamine and atropine were detected also in the floral nectar of Brugmansia and Datura species. From five Datura species studied, only D. tatula was characterized by the dominance of atropine, while the nectar of $D$. innoxia, D. metel, D. meteloides and D. stramonium, and also that of $B$. suaveolens contained higher ratio of scopolamine than atropine $[16,71]$. Nectar alkaloid concentrations in $D$. innoxia, D. metel and D. meteloides ranged from 58 to 400 , 85-132 and 120-190 $\mu \mathrm{g} / \mathrm{mL}$ scopolamine, and 2-37, 3-4 and $0.19-0.42 \mu \mathrm{g} / \mathrm{mL}$ atropine, respectively [16]. Consumption of Brugmansia or Datura flowers [34, 44, 65, 66] and/ or their secretory product, the nectar, may also cause severe anticholinergic symptoms. Nectar volumes in small-flowered species, such as D. quercifolia and D. stramonium are typically around $25 \mu \mathrm{L} /$ flower, whereas large-flowered species, e.g., B. suaveolens, $D$. innoxia and $D$. metel can produce substantial amounts, up to $150 \mu \mathrm{L}$ nectar per flower [71, 72]. Knowing that the toxic doses of atropine and scopolamine range between 2.0 and $6.5 \mathrm{mg}$ in case of oral administration [20], the ingestion of the nectar of 50-100 flowers can induce severe anticholinergic intoxication, if we calculate with an average nectar volume of $100 \mu \mathrm{L} /$ flower in largeflowered species [72] and an average nectar alkaloid concentration of $215 \mu \mathrm{g} / \mathrm{mL}$ [16]. Nectars containing tropane alkaloids may also be processed into toxic honeys, which may cause intoxication when ingested [73, 74].

\section{Conclusions}

Data of poison information centers from all over the world indicate that most exposures to Brugmansia and Datura are related to abuse, in connection with their hallucinogenic property, mostly in the age group of adolescents. Accidental ingestion is less frequent, but has been reported in small children, and also in adults who have mistaken various plant parts of the toxic species for their edible counterparts. Anticholinergic intoxication may also result from the improper use of traditional herbal medicines containing Datura. More recently, the use of Brugmansia and Datura as incapacitating drug in sexual crimes and robberies has caught the attention of authorities. The highest toxicological significance can be attributed to the flowers and seeds of Brugmansia and Datura, but exposure to the leaves and floral nectar can also cause intoxication.

Acknowledgements Open access funding provided by University of Pécs (PTE) is acknowledged. The authors are grateful to the Hungarian Toxicological Information Service for providing data on plant exposures in the period 2005-2017; and to the Doctoral Program in Biology and Sport Biology, University of Pécs, Hungary, for supporting our floral biological and nectar chemistry studies. 


\section{Compliance with ethical standards}

Conflict of interest There are no financial or other relations that could lead to a conflict of interest.

Ethical approval No ethical approval was required for the preparation of this type of article.

Open Access This article is distributed under the terms of the Creative Commons Attribution 4.0 International License (http://creativeco mmons.org/licenses/by/4.0/), which permits unrestricted use, distribution, and reproduction in any medium, provided you give appropriate credit to the original author(s) and the source, provide a link to the Creative Commons license, and indicate if changes were made.

\section{References}

1. Jaspersen-Schib R, Theus L, Guirguis-Oeschger M, Gossweiler B, Meier-Abt PJ (1996) Serious plant poisonings in Switzerland 1966-1994. Case analysis from the Swiss Toxicology Information Center. Schweiz Med Wochenschr 126:1085-1098 (PMID: 8711457) (in German with English abstract)

2. Lin TJ, Nelson LS, Tsai JL, Hung DZ, Hu SC, Chan HM, Deng JF (2009) Common toxidromes of plant poisonings in Taiwan. Clin Toxicol 47:161-168. https://doi.org/10.1080/155636508020779 24

3. Moro PA, Assisi F, Cassetti F, Bissoli M, Borghini R, Davanzo F, Della Puppa T, Dimasi V, Ferruzzi M, Giarratana T, Travaglia A (2009) Toxicological hazards of natural environments: clinical reports from Poison Control Centre of Milan. Urban For Urban Green 8:179-186. https://doi.org/10.1016/j.ufug.2009.02.007

4. Krenzelok EP, Mrvos R (2011) Friends and foes in the plant world: a profile of plant ingestions and fatalities. Clin Toxicol 49:142-149. https://doi.org/10.3109/15563650.2011.568945

5. Symon DE, Haegi L (1991) Datura (Solanaceae) is a new world genus. In: Hawkes JG, Lester RN, Nee M, Estrada N (eds) Solanaceae III: taxonomy, chemistry, evolution. Royal Botanic Gardens Kew, London, pp 197-210

6. Luna-Cavazos M, Bye R, Jiao M (2009) The origin of Datura metel (Solanaceae): genetic and phylogenetic evidence. Genet Resour Crop Evol 56:263-275. https://doi.org/10.1007/s1072 2-008-9363-5

7. Benítez G, March-Salas M, Villa-Kamel A, Cháves-Jiménez U, Hernández J, Montes-Osuna N, Moreno-Chocano J, Cariñanos P (2018) The genus Datura L. (Solanaceae) in Mexico and Spainethnobotanical perspective at the interface of medical and illicit uses. J Ethnopharmacol 219:133-151. https://doi.org/10.1016/j. jep.2018.03.007

8. Gallego MJ (2012) Datura L. In: Castroviejo S, Aedo C, Laínz M, Muñoz Garmendia F, Nieto Feliner G, Paiva J, Benedí C (eds) Flora iberica, vol. 11. CSIC, Madrid, pp 216-224 (in Spanish)

9. Schultes RE, Plowman T (1979) The ethnobotany of Brugmansia: Tommie Earl Lockwood. J Ethnopharmacol 1:147-164. https:// doi.org/10.1016/0378-8741(79)90004-7

10. Schultes RE, Farnsworth NR (1980) Ethnomedical, botanical and phytochemical aspects of natural hallucinogens. Bot Mus Leafl Harv Univ 28:123-214. https://www.jstor.org/stable/41762829

11. Griffin WJ, Lin GD (2000) Chemotaxonomy and geographical distribution of tropane alkaloids. Phytochemistry 53:623-637. https://doi.org/10.1016/S0031-9422(99)00475-6

12. Evans WC, Lampard JF (1972) Alkaloids of Datura suaveolens. Phytochemistry 11:3293-3298. https://doi.org/10.1016/S0031 $-9422(00) 86392-\mathrm{X}$
13. Miklós EJ, Botz L, Horváth G, Farkas Á, Dezső G, Szabó LG (2001) Atropine and scopolamine in leaf and flower of Datura arborea L. Int J Hortic Sci 7:61-64. https://doi.org/10.31421/ IJHS/7/2/268

14. Miraldi E, Masti A, Ferri S, Comparini IB (2001) Distribution of hyoscyamine and scopolamine in Datura stramonium. Fitoterapia 72:644-648. https://doi.org/10.1016/S0367-326X(01)00291-X

15. Berkov S, Zayed R (2004) Comparison of the tropane alkaloid spectra between Datura innoxia growth in Egypt and Bulgaria. Z Naturforsch C 59:184-186. https://doi.org/10.1515/ ZNC-2004-3-409

16. Boros B, Farkas Á, Jakabová S, Bacskay I, Kilár F, Felinger A (2010) LC-MS quantitative determination of atropine and scopolamine in the floral nectar of Datura species. Chromatographia (Suppl 1) 71:43-49. https://doi.org/10.1365/s10337-010-1524-y

17. Jakabová S, Vincze L, Farkas Á, Kilár F, Felinger A, Boros B (2012) Determination of tropane alkaloids atropine and scopolamine by liquid chromatography-mass spectrometry in plant organs of Datura species. J Chromatogr A 1232:295-301. https ://doi.org/10.1016/j.chroma.2012.02.036

18. Kerchner A, Darók J, Bacskay I, Felinger A, Jakab G, Farkas Á (2015) Protein and alkaloid patterns of the floral nectar in some solanaceous species. Acta Biol Hung 66:304-315. https://doi. org/10.1556/018.66.2015.3.6

19. Romera-Torres A, Romero-González R, Vidal JLM, Frenich AG (2018) Analytical methods, occurrence and trends of tropane alkaloids and calystegines: an update. J Chromatogr A 1564:1-15. https://doi.org/10.1016/j.chroma.2018.06.004

20. Diker D, Markovitz D, Rothman M, Sendovski U (2007) Coma as a presenting sign of Datura stramonium seed tea poisoning. Eur J Intern Med 18:336-338. https://doi.org/10.1016/j. ejim.2006.09.035

21. Bo T, Li KA, Liu HW (2003) Investigation of the effect of space environment on the contents of atropine and scopolamine in Datura metel by capillary zone electrophoresis. J Pharm Biomed Anal 31:885-891. https://doi.org/10.1016/S0731-7085(02)00670 $-2$

22. Hamilton MG, Lundy PM (2007) Medical countermeasures to WMDs: defence research for civilian and military use. Toxicology 233:8-12. https://doi.org/10.1016/j.tox.2006.08.034

23. Lukasewycz S, Holman M, Kozlowski P, Porter CR, Odom E, Bernards C, Neil N, Corman JM (2010) Does a perioperative belladonna and opium suppository improve postoperative pain following robotic assisted laparoscopic radical prostatectomy? Results of a single institution randomized study. Can J Urol 17:5377-5382 (PMID: 20974030)

24. Rapoport A (2010) Sublingual atropine drops for the treatment of pediatric sialorrhea. J Pain Symptom Manag 40:783-788. https:// doi.org/10.1016/j.jpainsymman.2010.02.007

25. Birmes P, Chounet V, Mazerolles M, Cathala B, Schmitt L, Lauque D (2002) Self-poisoning with Datura stramonium. 3 Case reports. Presse Med 31:69-72 (PMID: 11850988) (in French with English abstract)

26. Gupta SK, Peshin SS, Srivastara A, Kaleekal T (2003) A study of childhood poisoning at National Poisons Information Centre, All India Institute of Medical Sciences, New Delhi. J Occup Health 45:191-196. https://doi.org/10.1539/joh.45.191

27. Srivastava A, Peshin SS, Kaleekal T, Gupta SK (2005) An epidemiological study of poisoning cases reported to the National Poisons Information Centre, All India Institute of Medical Sciences, New Delhi. Hum Exp Toxicol 24:279-285. https://doi. org/10.1191/0960327105ht527oa

28. Marc B, Martis A, Moreau C, Arlie G, Kintz P, Leclerc J (2007) Acute Datura stramonium poisoning in an emergency department. Presse Med 36:1399-1403. https://doi.org/10.1016/j. lpm.2007.04.017 (in French with English abstract) 
29. Spina SP, Taddei A (2007) Teenagers with Jimson weed (Datura stramonium) poisoning. Can J Emerg Med 9:467-469. https://doi. org/10.1017/S1481803500015530

30. Oshiro N, Kuniyoshi K, Nakamura A, Araki Y, Tamanaha K, Inafuku K (2008) A case of food poisoning due to ingestion of eggplant, Solanum melongena, grafted on Devil's trumpet, Datura metel. J Food Hyg Soc Jpn 49:376-379. https://doi.org/10.3358/ shokueishi.49.376(in Japanese with English abstract)

31. Phua DH, Cham G, Seow E (2008) Two instances of Chinese herbal medicine poisoning in Singapore. Singap Med J 49:e131e133 (PMID: 18465037)

32. Wiebe TH, Sigurdson ES, Katz LY (2008) Angel's trumpet (Datura stramonium) poisoning and delirium in adolescents in Winnipeg, Manitoba: summer 2006. Paediatr Child Health 13:193-196 (PMID: 19252697)

33. Mohamad N, Baharuddin KA, Ahmad R (2009) A traditional Malay myth leading to unintentional self intoxication with kecubung fruit. Southeast Asian J Trop Med Public Health 40:1331-1334 (PMID: 20578469)

34. Disel NR, Yilmaz M, Kekec Z, Karanlik M (2015) Poisoned after dinner: dolma with Datura stramonium. Turk J Emerg Med 15:51-55. https://doi.org/10.5505/1304.7361.2015.70894

35. Trancă SD, Szabo R, Cociş M (2017) Acute poisoning due to ingestion of Datura stramonium - a case report. Rom J Anaesth Intensive Care 24:65-68. https://doi.org/10.21454/rjaic.7518.241. szb

36. Goldfarb J, Pesin N, Margolin E (2019) Gardening and dilated pupils: an interesting case of anisocoria from Brugmansia versicolor. Can J Ophthalmol 54:e59-e61. https://doi.org/10.1016/j. jcjo.2018.05.004

37. Urich RW, Bowerman DL, Levisky JA, Pflug JL (1982) Datura stramonium: a fatal poisoning. J Forensic Sci 27:948-954. https ://doi.org/10.1520/JFS12217J

38. Boumba VA, Mitselou A, Vougiouklakis T (2004) Fatal poisoning from ingestion of Datura stramonium seeds. Vet Hum Toxicol 46:81-82 (PMID: 15080209)

39. Steenkamp PA, Harding NM, van Heerden FR, van Wyk BE (2004) Fatal Datura poisoning: identification of atropine and scopolamine by high performance liquid chromatography/photodiode array/mass spectrometry. Forensic Sci Int 145:31-39. https://doi. org/10.1016/j.forsciint.2004.03.011

40. Le Garff E, Delannoy Y, Mesli V, Hédouin V, Tournel G (2016) Forensic features of a fatal Datura poisoning case during a robbery. Forensic Sci Int 261:e17-e21. https://doi.org/10.1016/j.forsc iint.2016.02.028

41. Lusthof KJ, Bosman IJ, Kubat B, Vincenten-van Maanen MJ (2017) Toxicological results in a fatal and two non-fatal cases of scopolamine-facilitated robberies. Forensic Sci Int 274:79-82. https://doi.org/10.1016/j.forsciint.2017.01.024

42. Isbister GK, Oakley P, Dawson AH, Whyte IM (2003) Presumed Angel's trumpet (Brugmansia) poisoning: clinical effects and epidemiology. Emerg Med 15:376-382. https://doi.org/10.104 6/j.1442-2026.2003.00477.X

43. Firestone D, Sloane C (2007) Not your everyday anisocoria: angel's trumpet ocular toxicity. J Emerg Med 33:21-24. https:// doi.org/10.1016/j.jemermed.2007.02.046

44. Sevketoglu E, Tatli B, Tuğcu B, Demirelli Y, Hatipoglu S (2010) An unusual cause of fulminant Guillain-Barré syndrome: angel's trumpet. Pediatr Neurol 43:368-370. https://doi.org/10.1016/j. pediatrneurol.2010.05.019

45. Chan K (2002) Jimson weed poisoning - a case report. Perm J 6(4):28-30 (PMC: 6220643)

46. Krenzelok EP (2010) Aspects of Datura poisoning and treatment. Clin Toxicol 48:104-110. https://doi.org/10.3109/1556365100 3630672
47. Centers for Disease Control and Prevention (CDC) (1995) Jimson weed poisoning-Texas, New York, and California, 1994. MMWR Morb Mortal Wkly Rep 44:41-44 (PMID: 7823893)

48. Soneral SN, Connor NP (2005) Jimson weed intoxication in five adolescents. Wisconsin Med J 104:70-72 (PMID: 16294604)

49. Mowry JB, Spyker DA, Cantilena LR Jr, Bailey JE, Ford M (2013) 2012 Annual report of the American Association of Poison Control Centers' National Poison Data System (NPDS): 30th Annual Report. Clin Toxicol 51:949-1229. https://doi.org/10.3109/15563 650.2013.863906

50. Mowry JB, Spyker DA, Cantilena LR Jr, McMillan M, Ford M (2014) 2013 Annual report of the American Association of Poison Control Centers' National Poison Data System (NPDS): 31st Annual Report. Clin Toxicol 52:1032-1283. https://doi. org/10.3109/15563650.2014.987397

51. Mowry JB, Spyker DA, Brooks DE, McMillan N, Schauben JL (2015) 2014 Annual report of the American Association of Poison Control Centers' National Poison Data System (NPDS): 32nd Annual Report. Clin Toxicol 53:962-1147. https://doi. org/10.3109/15563650.2015.1102927

52. Mowry JB, Spyker DA, Brooks DE, Zimmerman A, Schauben JL (2016) 2015 Annual report of the American Association of Poison Control Centers' National Poison Data System (NPDS): 33rd Annual Report. Clin Toxicol 54:924-1109. https://doi. org/10.1080/15563650.2016.1245421

53. Gummin DD, Mowry JB, Spyker DA, Brooks DE, Fraser MO, Banner W et al. (2017) 2016 Annual report of the American Association of Poison Control Centers' National Poison Data System (NPDS): 34th Annual Report. Clin Toxicol 55:1072-1252. https ://doi.org/10.1080/15563650.2017.1388087

54. Gummin DD, Mowry JB, Spyker DA, Brooks DE, Osterthaler KM et al. (2018) 2017 Annual report of the American Association of Poison Control Centers' National Poison Data System (NPDS): 35th Annual Report. Clin Toxicol 56:1213-1415. https://doi. org/10.1080/15563650.2018.1533727

55. Kanchan T, Atreya A (2016) Datura: the roadside poison. Wilderness Environ Med 27:442-443. https://doi.org/10.1016/j. wem.2016.04.007

56. Taha SA, Mahdi AH (1984) Datura intoxication in Riyadh. Trans R Soc Trop Med Hyg 78:134-135. https://doi.org/10.1016/00359203(84)90196-2

57. Chang SS, Wu ML, Deng JF, Lee CC, Chin TF, Liao SJ (1999) Poisoning by Datura leaves used as edible wild vegetables. Vet Hum Toxicol 41:242-245 (PMID: 10434380)

58. Onen CL, Othol D, Mbwana SK, Manuel IL (2003) Datura stramonium mass poisoning in Botswana. S Afr Med J 92:213-214 (PMID: 12040948)

59. Gaire BP, Subedi L (2013) A review on the pharmacological and toxicological aspects of Datura stramonium L. J Integr Med 11:73-79. https://doi.org/10.3736/jintegrmed2013016

60. Chan TY (1995) Anticholinergic poisoning due to Chinese herbal medicines. Vet Hum Toxicol 37:156-157 (PMID: 7631497)

61. van Wyk B-E, Oudtshoorn B, Gericke N (2002) Medicinal plants of South Africa, 2nd edn. Briza Publications, Pretoria

62. Adegoke SA, Alo LA (2013) Datura stramonium poisoning in children. Niger J Clin Pract 16:116-118. https://doi. org/10.4103/1119-3077.106783

63. Moore DM (1972) Datura L. In: Tutin TG, Heywood VH, Burges NA, Moore DM, Valentine DH, Walters SM, Webb DA (eds) Flora Europaea, vol. 3. Cambridge University Press, Cambridge, pp 200-201

64. Osváth P, Nagy A, Fekete S, Tényi T, Trixler M (2000) A case of Datura stramonium poisoning_-general problems of differential diagnosis. Orv Hetil 141:133-136 (PMID: 10693336) (in Hungarian with English abstract) 
65. Winckelmann U, Lübke G, Brockstedt M, Schanz I, Dechent J, Weber J, Albani M (2000) Anticholinerges Syndrom nach Ingestion von Tee aus Engelstrompetenblüten. Monatsschr Kinderheilkd 148:18-22. https://doi.org/10.1007/s001120050004

66. Lazzarini D, Baffoni MT, Cangiotti C, Di Fronzo G, Gerboni S, Micheli R, Morelli S, Morolli L, Ioli G (2006) Food poisoning by Datura stramonium: an unusual case report. Intern Emerg Med 1:88-90. https://doi.org/10.1007/BF02934733

67. Rätsch C (1998) The encyclopedia of psychoactive plants: ethnopharmacology and its applications. Park Street Press, Rochester

68. Lindequist U (1992) Datura. In: Blaschek W, Hänsel R, Keller K, Reichling J, Rimpler H, Schneider G (eds) Hagers Handbuch der Pharmazeutischen Praxis, 5th edn. Springer, Berlin, pp $1138-1154$

69. Caligiani A, Palla G, Bonzanini F, Bianchi A, Bruni R (2011) A validated GC-MS method for the detection of tropane alkaloids in buckwheat (Fagopyron esculentum L.) fruits, flours and commercial foods. Food Chem 127:204-209. https://doi.org/10.1016/j. foodchem.2010.11.141

70. Ciechomska M, Woźniakiewicz M, Nowak J, Świadek K, Bazylewicz B, Kościelniak P (2016) Development of a microwave-assisted extraction of atropine and scopolamine from
Solanaceae family plants followed by a QuEChERS clean-up procedure. J Liq Chromatogr Relat Technol 39:538-548. https:// doi.org/10.1080/10826076.2016.1196215

71. Kerchner A (2019) Néhány Solanaceae faj nektárkémiai és virágbiológiai vizsgálata. PhD dissertation. University of Pécs, Pécs, Hungary (in Hungarian with English summary)

72. Farkas Á, Kerchner A, Déri H, Boros B, Darók J (2011) Nectary structure and nectar production of various Datura species. Int J Plant Reprod Biol 3:31-35

73. Marciniak J, Sikorski M (1972) Poisoning by alkaloids of Datura stramonium and $D$. inoxia after ingestion of honey. Pol Tyg Lek 27:1002-1003 (PMID: 5068984) (in Polish)

74. Ramirez M, Rivera E, Ereu C (1999) Fifteen cases of atropine poisoning after honey ingestion. Vet Hum Toxicol 41:19-20 (PMID: 9949478)

Publisher's Note Springer Nature remains neutral with regard to jurisdictional claims in published maps and institutional affiliations. 